Original Research Paper

\title{
Digitasi Lahan Pertanian Kopi Kelompok Tani Mule Jati Desa Batu Mekar, Kecamatan Lingsar
}

\author{
Cahyo Mustiko $^{1 *}$, I Gede Putu Laba Sepriyadi Sudhiarsana ${ }^{2}$, Anugrah Fajar Dirgantara Akbar ${ }^{3}$, \\ Galuh Karin Puspita Sari ${ }^{4}$, Sandhi Wahdania ${ }^{5}$
}

${ }^{1}$ Program StudiTeknik Elektro,Universitas Mataram, Indonesia

${ }^{2}$ Program Studi Ilm uHukum,Universitas Mataram, Indonesia

${ }^{3}$ Program Studi Ilmu Hukum,Universitas Mataram, Indonesia

${ }^{4}$ Program Studi Ekonomi Pembangunan, Universitas Mataram, Indonesia

${ }^{5}$ Program Studi Ilmu Komunikasi, Universitas Mataram, Indonesia

https://doi.org/10.29303/jpmpi.v3i2.943

Sitasi: Mustiko, C., Sudhiarsana, I. G. P. L. S., Akbar, A. F. D., Sari, G. K. P \& Wahdania. (2021). Digitasi Lahan Pertanian Kopi Kelompok Tani Mule Jati Desa Batu Mekar, Kecamatan Lingsar. Jurnal Pengabdian Magister Pendidikan IPA, 4(3)

\section{Article history}

Received: 31 Juli 2021

Revised: 2 September 2021

Accepted: 6 September 2021

*Corresponding Author:

Cahyo Mustiko, Program

Studi Teknik Elektro,

Universitas Mataram,

Indonesia

Email:

mustiko_cahyo@yahoo.co.uk

\begin{abstract}
Abstrak: Modernisasi pertanian salah satunya adalah membangun sistem informasi berbasis digital untuk mengelola aset produksi onfarm pada komoditas tertentu. Kopi adalah salah satu komoditas kebun strategis dan memberikan nilai tambah besar kepada pelaku tani diwilayah sekitar hutan. Kegiatan pengabdian ini adalah membangun digitasi kopi pada kelompok tani Mule Jati, Bau Mekar, Lombok Barat. Teknik digitasi dengan membangun data spasial dan atribut lahan kopi milik anggota petani. Hasil data atribut diolah dengan dukungan software ArcGIS 10.6. Hasil data spasial diperoleh luasan areal penanaman kopi seluas 8,6 Ha dengan ketinggian antara 550-600 mdpl. Jumlah produksi biji kopi rata-rata 3,9 ton per Ha yang diperoleh dari pohon kopi usia 2-7 tahun. Periode panen kopi pada bulan Juli-Agustus untuk setiap musimnya. Kendala yang mengancam dari pohon kopi adalah keberadaan serangga rayap yang memungkinkan dapat mengganggu pertumbuhan pohon kopi. Pohon kopi akan baik jika dilakukan regenerasi 15 tahun kedepan untuk menjaga produktivitas. Hasil estimasi produksi kopi maksimal di kelompok Mule Jati sebesar 68,8 ton per musim atau dapat meningkat $100 \%$ setelah 15 tahun kedepan.
\end{abstract}

Kata kunci : ArcGIS, modernisaai, produksi, regenerasi, serangga,

\section{Pendahuluan}

Desa Batu Mekar merupakan salah satu desa yang ada di Kecamatan Lingsar, Kabupaten Lombok Barat. Desa ini memiliki jumlah penduduknya sebagian besar bersuku daerah sasak terletak dibagian barat Pulau Lombok. Desa Batu Mekar memiliki luas sebesar 841,97 Ha. Dengan perincian : Luas Tanah Sawah sebesar 233,00 Ha, Luas Tanah Kering Sebesar 48,18 Ha, Luas Tanah Perkebunan sebesar 185,15 Ha, Luas Fasilitas Umum sebesar 9,19 Ha, dan Luas Tanah Hutan sebesar 366,45 Ha. (Sumber Data : Pemerintah Desa).
Revolusi Industri 4.0 telah melahirkan kehidupan baru masyarakat dunia dengan seluruh layanannya. Perubahan dalam segala lini kehidupan tidak terelakkan. Orientasi hidup manusia mengalami pergeseran begitu tajam, yang pada ujungnya menimbulkan banyak kekhawatiran pada aspek keberlanjutan. Society 5.0 yang disuarakan oleh pemerintah Jepang pada awal tahun 2019 mengajak kepada seluruh umat manusia di dunia untuk dapat berpikir kritis dan kembali kepada nilai-nilai kemanusiaan seutuhnya dalam menyikapi perkembangan teknologi. Aspek keberlanjutan menjadi kunci utama dan harapan adanya sikap positif terhadap era Society 5.0 (Suswandari 2019). 
Dalam society 5.0 digambarkan bahwa setiap kegiatan yang dilakukan manusia sangat bergantung kepada teknologi. Teknologi sudah menjadi kebutuhan dasar dalam sendi-sendi kehidupan manusia, semua terintegrasi dengan smartphone. Dalam transaksi bisnis masyarakat juga sudah tergantung dengan teknologi sehingga tidak mau lagi melakukan transaksi bisnis secara tradisional

Selanjutnya, era pertanian modern saat ini tidak lepas dari kebutuhan peranan sistem informasi terhadap desa untuk memudahkan dalam memberikan informasi yang cepat, akurat, dan relevan. Ketersediaan fasilitas yang diberikan oleh sistem infromasi dapat membangun sinergi antar desa berbasis teknologi informasi. Dari sini, harapan diharapkan terbangunnya bisnis, penjualan produksi-produksi desa ke kota lewat sarana ekonomi digital. Bahkan dengan kertersediaan data yang baik akan mendukung kekuatan komoditas dalam rantai perdagangan. Untuk itu, bangunan data akan sangat diutamakan dalam membangun sistem informasi seperti pada kasus bidang pertanian.

Sistem Informasi Geografis (SIG) merupakan sistem yang dirancang untuk bekerja dengan data yang tereferensi secara spasial atau koordinat-koordinat geografi. Sistem informasi geografis adalah bentuk sistem informasi yang menyajikan informasi dalam bentuk grafis dengan menggunakan peta. Perkembangan teknologi digital sangat besar peranannya dalam perkembangan penggunaan SIG dalam berbagai bidang (Wowor, 2013). Penggunaan sistem informasi geografi (SIG) dapat mendukung suatu sistem kerja yang efektif dan efisien serta memudahkan dalam perencanaan, pemantauan, pemeliharaan, pengembangan dan membantu dalam pengambilan keputusan ( Donya dan Sasmito, 2020).

Beberapa contoh aplikasi-aplikasi SIG di beberapa bidang sebagai ilustrasi (Prahasta, 2002) seperti di sumber daya alam, perencanaan, kependudukan, lingkungan. Manajemen utility, pertanahan, pariwisata, militer, geologi, pertambangan, dan lain-lain. Untuk itu, tulisan ini bertujuan untuk membangun data spasial informasi perkebunan kopi rakyat pada kelompok tani Mule Jati yang ada di desa Batu Mekar, Lingsar, Lombok Barat.

\section{Metode}

Pelaksanaan kegiatan pengabdian dengan target pembangunan sistem informasi pertanian kopi kelompok tani Mule Jati di laksanakan pada bulan Juni sampai Agustus 2021. Lokasi di lahan perkebunan kopi kelompok tani yang terdiri atas 30 atau dari total lahan milik anggota sejumlah 30 orang.

\section{Bahan dan Alat}

Alat yang digunakan terdiri dari perangkat keras (hardware) dan perangkat lunak (software). Perangkat keras yaitu GPS Garmin 60CSX dan Garmin 62S, smartphone, buku catatan dan peralatan tulis. Adapun perangkat lunak yaitu excel, ArcMap, Google Earth dan arcGIS online.

\section{Prosedur Pelaksanaan}

Pelaksanaan kegiatan pembangunan digitasi kopi di desa Batu Mekar, Lingsar, Lombok Barat mengikuti langkah sebagai berikut:

1. Identifikasi Masalah

Melakukan identifikasi masalah dengan mewawancarai petani kopi di kelompok tani Mule Jati, Kecamatan Lingsar, Kabupaten Lombok Barat. Permasalahan yang didapat salah satunya adalah tidak adanya pendataan terkait perkiraan luasan kebun kopi dan data produksi.

2. Studi Literatur

Melakukan penelusuran informasi-informasi melalui jurnal-jurnal penelitian dan buku-buku terkait implementasi ArcMap dan ArcGIS Online terhadap pembuatan Sistem Informasi Geografis (SIG) yang dapat mendukung proses pendataan produksi komoditas tanaman di suatu lahan pertanian.

3. Pengambilan data.

Melakukan pengambilan data-data spasial dan atribut terkait pembuatan database dan SIG.

4. Digitasi dan pengolahan data

Melakukan pengolahan data-data menggunakan program Excel sebagai dasar digitasi data-data pertanian dan pembuatan peta beserta atributatribut pendukung dengan program ArcMap.

5. Verifikasi Data

Melakukan verifikasi terhadap hasil peta pertanian yang telah dibuat kepada petani di di kelompok tani Mule Jati, Kecamatan Lingsar, Kabupaten Lombok Barat untuk antisipasi 
kurang atau salahnya data-data yang ditampilkan di peta pertanian tersebut.

6. Sistem Informasi Geografis lahan pertanian di di kelompok tani Mule Jati, Kecamatan Lingsar, Kabupaten Lombok Barat.

Menampilkan hasil pemetaan beserta atributatribut menggunakan ArcGIS sehingga informasi-informasi terkait potensi produksi komoditas kopi dapat diprediksi

\section{Hasil dan Pembahasan}

\section{Profil Kelompok Tani Mule Jati}

Di Desa Batu Mekar terdapat 1 (satu) kelompok petani kopi yaitu Mule Jati. Kelompok tani beranggotakan 20 orang termasuk ketua, sekertaris,dan bendahara. Para petani kopi Mule Jati menggarap lahan perkebunan kopi yang masih merupakan lahan Hutan Kemasyarakatan (HKm). Hasil dari biji kopi atau sering disebut kopi gelondongakan dijual langsung ke pengepul luar dan juga akan dikelola menjadi bubuk kopi apabila adanya pesanan. Pola penjualan hasil panen anggota kelompok masih secara sendiri-sendiri dan belum ada tata kelola bagian dari hasil penjualan untuk menjadi aset kelompok tersebut.

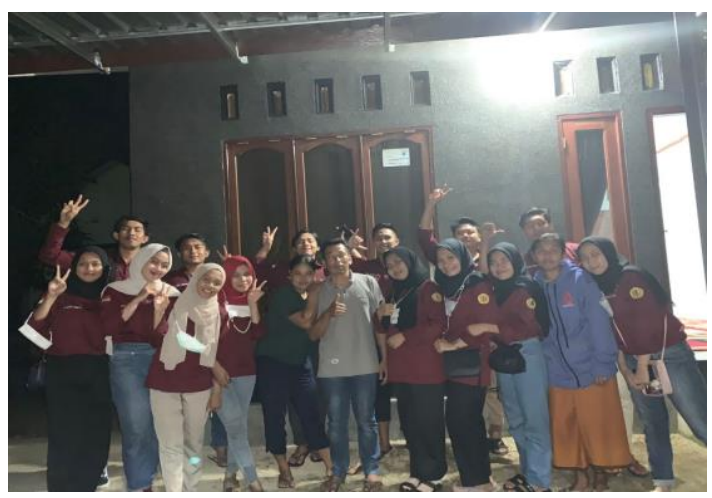

Gambar 1 Sosialisasi digitasi data kopi di kelompok tani Mule Jati

Hasil kopi yang ada di Desa Batu Mekar merupakan kopi berjenis Robusta, jenis kopi ini lebih mudah dalam proses panen. Proses pembuatan kopi di Desa di Desa Batu Mekar Masih menggunakan cara tradisonal, sebelum kopi dapat diminum melalui proses yang panjang, yaitu dari pemanenan biji kopi yang telah matang kemudian dilakukan proses pengeringan atau penjemuran sebelum menjadi kopi gelondong.

\section{Pengumpulam Informasi dalam Membangun Database Kopi Mule Jati}

Peran database komoditas pertanian sangat penting dalam mendukung tata niaga kopi pada tingkat hulu. Pembuatan digitasi data kopi yang dimiliki oleh kelompok tani Mule Jati dengan membangun data spasial memiliki peran strategis dalam mendukung bangunan sistem informasi pertanian modern. Tim database melakukan

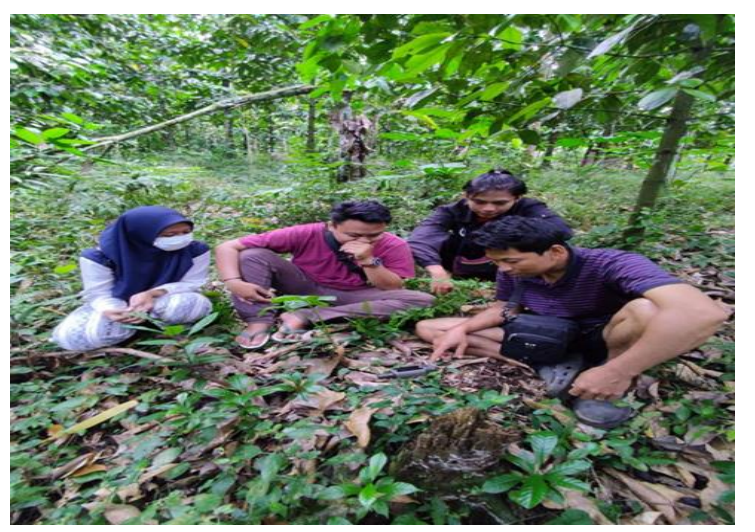

pengumpulan data seperti gambar dibawah ini.

Gambar 2 Pemetaan lahan kopi kelompok tani Mule Jati

Lahan kopi diambil koordinatnya manggunakan GPS untuk memperoleh lokasi atau kordinat lahan tersebut. Proses pengambilan titik kurang lebih 5 menit. Setiap titik sudut lahan kopi yang ada pada lahan petani kelompok Mule Jati disimpat dalam bentuk koordinat luas lahan kopi. Data digital yang bersifat kewilayahan dapat dibangun melaui pendekatan secara spasial. Perkembangan digital sangat besar perannya dalam perkembangan penggunaan SIG dalam berbagai bidang. Keberadaan kopi yang dikelola oleh kelompok Mule Jati dirangkum dalam bangunan sistem informasi yang diwakilkan oleh keberadaan informasi data spasial. Berikut adalah hasil pengembangan sistem informasi pertanian kopi pada kelompok Mule Jati. 

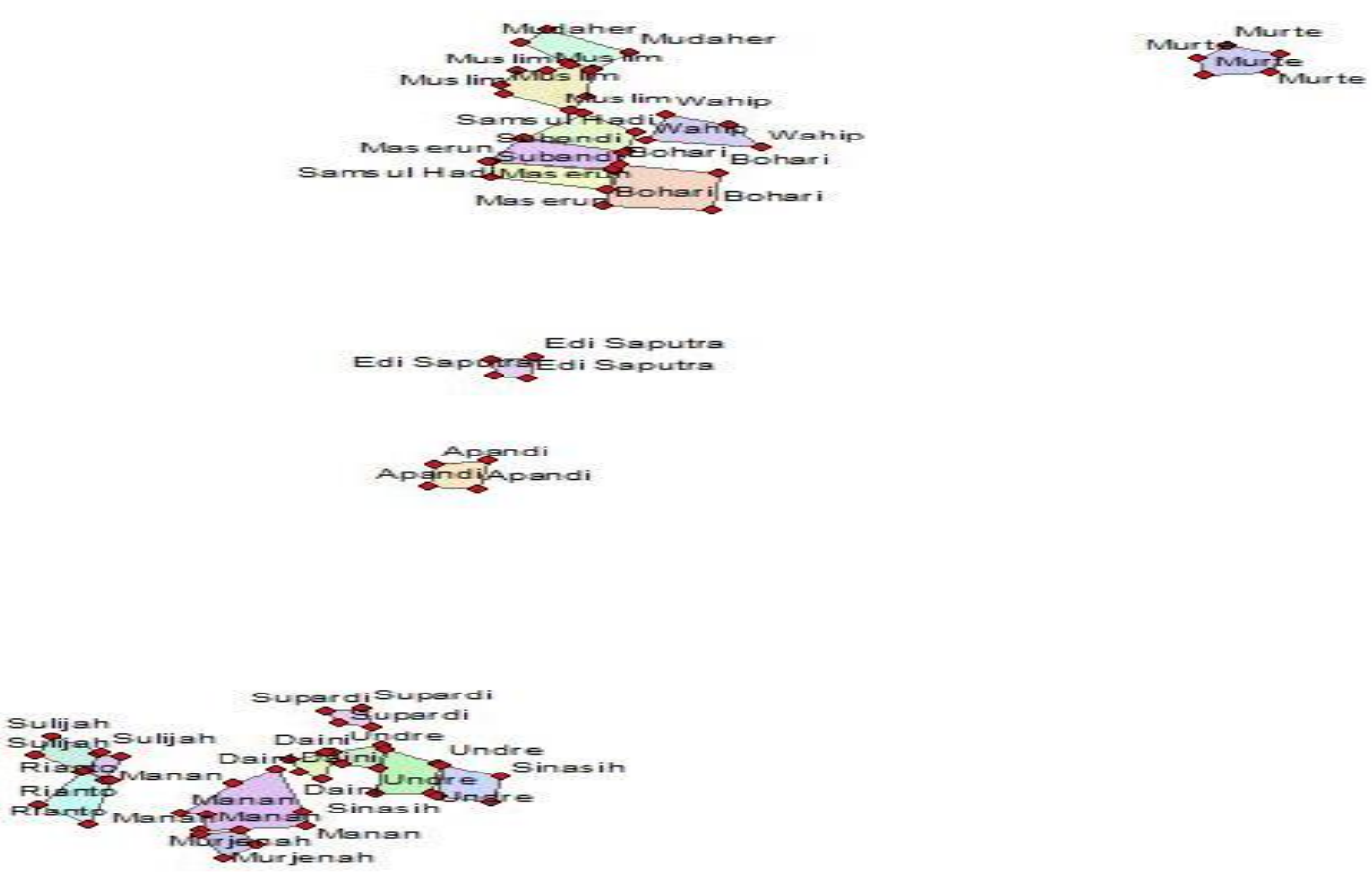

Gambar 2 Digitasi spasial lahan kopi kelompok tani Mule Jati

jarak luas antar pohon 15 sampai dengan 42 meter.

Hasil data spasial yang diperoleh dari hasil pengukuran lapangan setelah pengolahan data, didapatkan luas lahan penanaman kopi seluas 12,09 Ha. Pohon kopi yang tertanam di lahan tersebut sebanyak 6.875 pohon dengan distribusi umur berkisar antara 2-7 tahun. Berdasarkan sebaran luasan lahan, pohon kopi tumbuh pada lahan petani yang semakin luas. Jumlah pohon kopi yang paling rendah pada lahan tanam seluas $0,2 \mathrm{Ha}$ dimana jumlah pohon kopi yang tersebar sebanyak 65-100 pohon. Jarak tanam pohon kopi ideal adalah $2 \times 3$ $m$ untuk setiap pohon atau sebanayk 1600 sampai 2000 pohon per Ha.

Periode musim panen kopi di kelompok mani Mule Jati pada bulan Juli-Agustus. Hasil perhitungan dari sebaran kopi yang ditanam anggota kelompok tani Mule Jati yang ideal adalah lahan tanam kopi Syamsulhadi, Manan dan Sahbandi dimana luas jarak tanam antar pohon antara 5-6 meter. Untuk anggota kelompok tani lainnya jarak tanam pohon kopi terlalu jauh karena
Jarak tanam yang semakin jauh akan berdampak kepada jumlah pohon yang berbuah dan hasil produksi per musim. Hasil panen per musim untuk luas areal tanam 8,6 Ha sekitar 34,35 ton atau kalau dirata-rata sebesar 3.99 ton per Ha. Hasil produksi per luasan pohon kopi yang tumbuh di Mule Maju termasuk sangat bagus karena rata rata kopi dapat diproduksi sebesar 4,1 ton per Ha (Karyani 2019).

Serangga juga menyerang pohon kopi yang ditanam kelompok tani Mule Jati. Hasil pengamatan terhadap penyebaran serangga penyerang kopi di dominasi oleh serangan rayap. Sumber asal dari rayap berasal dari lingkungan sekitar kebun. Bagian pangkal pohon dekat tanah akan dijumpai rumah rayap dan menimbulkan pengelupasan kulit batang kopi mengelupas, rantai kering dan daun rontok. Namun, efek masif dari serangan rayap tidak menyebabkan pohon kopi mati karena pohon kopi dapat memberikan efek imun atau memperbaiki sendiri dari kerusakan kopi. 
Tabel 1. Data atribut kopi kelompok tani Mule Jati

\begin{tabular}{|c|c|c|c|c|c|}
\hline No & Kode Lahan & Luas Lahan (Ha) & $\begin{array}{l}\text { Jumlah Pohon } \\
\text { Kopi (Pohon) }\end{array}$ & $\begin{array}{c}\text { Usia Pohon } \\
\text { Kopi }\end{array}$ & $\begin{array}{c}\text { Jumlah Hasil Panen Per } \\
\text { Musim }(\mathrm{Kg})\end{array}$ \\
\hline 1 & JMSN & 0,49 & 70 & 4 Tahun & 35 \\
\hline 2 & JSKI & 0,15 & 65 & 2 Tahun & 45 \\
\hline 3 & JBRI & 0,95 & 975 & 6 Tahun & 8500 \\
\hline 4 & JSPD & 0,12 & 150 & 3,5 Tahun & 1750 \\
\hline 5 & JAPI & 0,3 & 225 & 5 Tahun & 250 \\
\hline 6 & JSIH & 0,39 & 450 & 2.5 Tahun & 550 \\
\hline 7 & JURE & 0,49 & 500 & 3 Tahun & 150 \\
\hline 8 & JMNN & 1,04 & 900 & 5 Tahun & 7000 \\
\hline 9 & JSLJ & 0,27 & 100 & 2 Tahun & 1000 \\
\hline 10 & JESH & 0,16 & 150 & 2 Tahun & 50 \\
\hline 11 & JMDR & 0,49 & 100 & 3 Tahun & 50 \\
\hline 12 & JRNT & 0,46 & 450 & 5 Tahun & 4000 \\
\hline 13 & JSNI & 0,61 & 500 & 7 Tahun & 7500 \\
\hline 14 & JSNT & 0,19 & 120 & 2 Tahun & 35 \\
\hline 15 & JSHI & 0,58 & 700 & 4 Tahun & 500 \\
\hline 16 & JDIN & 0,15 & 100 & 2 Tahun & 50 \\
\hline 17 & JWHP & 0,5 & 600 & 2 Tahun & 350 \\
\hline 18 & JMJH & 0,21 & 120 & 2 Tahun & 35 \\
\hline 19 & JMLM & 0,63 & 100 & 4 Tahun & 1000 \\
\hline 20 & JMRT & 0,42 & 500 & 3 Tahun & 1500 \\
\hline
\end{tabular}

Melengkapi dari Gambar 2, rincian atribut pemetaan kopi di Mule Jati tersusun pada Tabel 1. Umur kopi yang ditanam oleh anggota kelompok tani setelah berkisar antara 2-7 tahun. Usia pohon 2 tahun adalah fase kopi mulai berbuah dan akan terus berbuah sampai usia 100 tahun meskipun pada usia dibawah 20 tahun adalah usia ideal untuk menghasilkan kuantitas dan kualitas biji kopi yang baik. Umumnya, pada periode umur 15-20 tahun dilakukan regenerasi pohon untuk menjaga hasil produksi. Produksi kopi yang dimiliki oleh para petani sangat bergantung dari luasan dan umur pohon. Kode JBRI mengahsilkan produksi sebesar 8,5 ton per musim dengan luasan lahan sebesar 0.95 Ha karena jarak distribusi pohon sangat baik yaitu 8 $\mathrm{m}^{2}$ dan umur pohon sangat produtif berusia 7 tahun.

Berdasarkan dari data spasial dan atribut yang telah terbangun, proyeksi produksi untuk 15 tahun kedepan akan menghasilkan produksi yang lebih besar dibandingkan dengan saat ini. Estimasi produksi untuk periode sebelum regenerasi kopi atau 15 tahun ke depan sebesar 68,8 atau hampir mencapai $100 \%$ dari hasil produksi saat ini. Asumsi ini tercapai apabila praktek perawatan pohon kopi seperti yang dilakukan sekaran ini tetap berjalan.

\section{Kesimpulan}

Hasil digitasi kebun kopi Mule Jati dapat digunakan untuk menghitung kapasitas produksi kopi saat ini dan untuk prediksi beberapa tahun kedepan. Hasil digitasi kebun kopi di kelompok Mule Jati diperoleh informasi lahan penanaman kopi seluas 8,6 Ha dengan areal tanam secara multikultur. Pohon kopi yang tumbuh mendapatkan suplai nutrisi secara alami tanpa adanya pemupukan sintetis. Hasil produksi kopi di Mule Jati mendekati 4 ton per Ha dengan periode panen pada bulan JuliAgustus. Jumlah petani yang terlibat dalam usaha produksi kopi sebanyak 20 petani dengan luas lahan beragam antara $0,1 \mathrm{Ha}$ sampai dengan $1 \mathrm{Ha}$. Pemasaran hasil panen kopi tersebar untuk pasar lokal Lombok dengan harga fluktuatif berkisar antara Rp 15.000-20.000 


\section{Saran}

Tim penulis memberikan saran untuk membangun sistem informasi pertanian lebih detail dan pengolahan citra untuk meningkatkan tampilan SIG kopi pada kelompok tani Mule Jati.

\section{Ucapan Terima Kasih}

Penulis mengucapkan terima kasih kepada kelompok tani Mule Jati, tim KKN Tematik Universitas Mataram di desa Batu Mekar, LPPM Universitas Mataram utnuk menyelesaikan kegiatan pengabdian ini.

\section{Daftar Pustaka}

Karyani. 2019. "Impact of Coffee Croppingpatterns on Farmer Income (a Case in Pulosari Village, Pangalengan District, Bandung).” 53(9):168999.

Muhammad Agam Cakra Donya, Bandi Sasmito, Arief Laila Nugraha. 2020. "Visualisasi Peta Fasilitas Umum Kelurahan Sumurboto Dengan Arcgis Online." Jurnal Geodesi Undip 9(oktober):52-58.

Manongga, D., Papilaya, S. dan Pandie, S. 2009. Sistem Informasi Geografis untuk Perjalanan Wisata di Kota Semarang. Jurnal Informatika. vol 10, hal 1-9

Suswandari. 2019. "Ekstrapolasi Paradigma Penddik Dan Kearifan Kebudayaan Dalam Menyambut Society 5.0." Prosiding Seminar Nasional Pendidikan Dan Pembelajaran 3(2014):1689-99.

Wowor, Aneke. 2013. Pemanfaatan Aplikasi GIS untuk Pemetaan Potensi Pertanian di Kabupaten Minahasa Utara. Jurnal Teknik Informatika. vol 2(1), hal 1-9. 